\title{
THE CORRECT STATUS OF “FRAGM. TYPI” INTRODUCED BY KLÁRA VERSEGHY
}

\author{
Ayhan ŞENKARDEŞLER \\ Department of Biology, Faculty of Science, Ege University, \\ Bornova, 35100 Izmir, Turkey; ayhan.senkardesler.mm@gmail.com
}

Şenkardeşler, A. (2019): The correct status of “Fragm. typi” introduced by Klára Verseghy. - Studia bot. hung. 50(2): 299-305.

\begin{abstract}
Klára Verseghy used the term "Fragm. typi" in her catalogue of the type specimens deposited in BP. However, this status is in conflict with the Code. "Fragm. typi" were replaced by lectotype and isolectotype of the following names: Buellia samothrakiana, Caloplaca servitiana, Catillaria servitii, Catillaria zsakii, Lecania nylanderiana var. ochracea, Lecanora atra var. aegaeica, L. cengiae-samboae, L. rhodi, Lecidea aegaeica f. acrustacea and Rinodina samothrakiana.
\end{abstract}

Key words: Greece, Hungary, Iran, lichens, lichenized Ascomycota, typification

\section{INTRODUCTION}

VERSEGHY (1964) compiled a catalogue of the type specimens deposited in BP, which was supplemented three times (VERSEGHY 1968, 1974, 1981). Ödön Szatala's type specimens were among them. As stated in ŞENKARDEŞLER et al. (2014), some of those specimens were collected by several collectors for the Natural History Museum in Vienna (W), sent to Ödön Szatala for identification, and as a result of supposed agreements duplicates or pieces of many type specimens were retained in BP. Specimens retained in BP were labelled in Latin with handwriting, while collection dates were missed on labels. Contrary, all returned specimens to $\mathrm{W}$ were rewritten subsequently by a typewriter in German and the collecting dates were added during this postprocess. For this reason, the labels on specimens deposited in $\mathrm{W}$ must be tracked to determine their collecting date.

Verseghy listed some specimens under the informal status category "Fragm. typi", perhaps meaning that the specimen in BP was a part of the material used for the description. Contrary to the meaning of the term "fragmentum", our examination of these specimens has revealed that they represent more than small pieces of the type material. In most cases, specimens at BP listed as "Fragm. typi" by Verseghy are duplicated at W. 
Regardless, Verseghy's usage of "Fragm. typi" cannot constitute lectotypification because the term is clearly intended to refer to a "fragment of the type" rather than the "holotype" or its equivalent. In this study, we will provide the correct type status for her "Fragm. typi".

\section{MATERIALS AND METHODS}

Type specimens of names in BP and W described by Ödön Szatala were exhaustively searched for during several projects, which had a main focus on finding taxa that had been reported from Turkey and Southwest Asia. Searching and analysing the material of both herbaria took five months, and about 300,000 specimens were checked envelope-by-envelope. The studies in Vienna were undertaken from May to September 2007 and February to March 2008, and in Budapest from November to December 2006, September 2008 and June to July 2011. During this process, every type specimen was annotated as such and transferred to the type cabinets in the relevant institutions. All newly discovered types are cited here with their herbarium accession number.

Locality information is here provided in the same form as written on the original labels, with recent names added in square brackets; Аввотт (2009) was used for Greek names, and Microsoft Encarta Interactive World Atlas 2000 for other place names.

Specimens were studied by standard light microscopy.

\section{RESULTS}

1. Buellia samothrakiana Szatala in Denkschr. Akad. Wiss. Wien, Math.-Naturwiss. Kl. 105(1): 54 (1943)

Lectotype (designated in ŞENKARDEŞLER et al. 2014): [Greece], Samothraki, Hagia Sophia [Agia Sophia], supra saxa, without date, K. H. Rechinger fil. s. n. (BP No. 34009 [T No. 892]!).

Only one specimen was found in BP, which was listed by VERSEGHY (1964) as "Fragm. typi", whereas none in W. Since the deposition of the type was not indicated in the protologue, the only available specimen was designated as the lectotype in ŞEN KA RDEŞLER et al. (2014). However, the taxonomic status of Buellia samothrakiana remained still unresolved. 
2. Caloplaca servitiana Szatala in Denkschr. Akad. Wiss. Wien, Math.-Naturwiss. Kl. 105(1): 51 (1943)

Lectotype (designated in VONDRÁK et al. 2010): [Greece], Samos, monte Kierki auf Kalk, 16-20. Juni 1932, K. H. Rechinger fil. s. n. (BP No 34015 (T 865)!, isolectotype (in VondRÁK et al. 2010): W No 1960-9203!).

VerSEghy (1964) cited "Fragm. typi" for the material deposited in BP. Later, VONDRÁK et al. (2010), lectotypified the specimen in BP and adopted isolectotype for the material in W. Since an internal indication is missing in the whole protologue (RECHINGER 1943, SzATALA 1943), where all the specimens are deposited, the lectotypification of VONDRÁK et al. (2010) is correct and ought to be followed. This species is a well-defined taxon (VONDRÁK et al. 2010).

3. Catillaria servitii Szatala in Denkschr. Akad. Wiss. Wien, Math.-Naturwiss. Kl. 105(1): 29 (1943)

Replacement lectotype (designated in ŞENKARDEŞLER et al. 2014): [Greece], Rhodos [Rhodes], Mt. Profeta [Mt. Profitis Ilias], ca. 700 m, supra corticem Pini brutiae, without date, K. H. Rechinger fil. s. n. (BP No. 34019 [T No. 238]!; isolectotype: $\mathrm{M}$, barcode M-0061228). The isolectotype was listed as isotype by Printzen (1995).

The deposition of the type of Catillaria servitii was not indicated in the protologue (ReChinger 1943, SZATALA 1943); Verseghy (1964) listed the specimen in BP as a "Fragm. typi", but this does not constitute lectotypification. On the other hand, PRINTZEN (1995) cited a specimen in W as the holotype of this name and specimens in BP and M as isotypes. Printzen's usage of "holotype" would be treated as a lectotypification, however, the specimen from $\mathrm{W}$ was not found during our exhaustive searches. For this reason, the specimen in BP, which fits the protologue, was designated as the replacement lectotype in ŞENKARDEŞLER et al. (2014). This species is a well-accepted taxon, and C. praedicta was accepted as its synonym (ŞENKARDEŞLER et al. 2014).

4. Catillaria zsakii Szatala in Magyar Bot. Lapok 24 (1925): 108 (1926)

Lectotype (designated in ŞENKARDEŞLER et al. 2014): [Hungary] Karczag [Karcag], a vasutállomástól délre szikes legelőn (Papér), 29 [“26”] Jul. 1926, Z. Zsáks.n. (BP No. 8110 [T No. 239/a]!; isolectotypes: BP No. 8106!, BP No. 8112 [T No. 239/b]!). 
The protologue of this name (SzATALA 1926) did not indicate where the type was deposited and at least three specimens are extant. Among them, VerSEgHY (1964) categorised the specimen BP 8110 ( $\mathrm{T}$ 239/a) as an isotype (its BP number mistyped as 9110 in the catalogue) and the specimen BP 8112 ( $\mathrm{T} \mathrm{239/b)}$ as "Fragm. typi", while the specimen BP 8106 was not included in her catalogue. The isotype of Verseghy was designated as lectotype in ŞENKARDEŞLER et al. (2014), and her "Fragm. typi" became an isolectotype. In addition, this name was regarded as a synonym of Micarea melaenida (COPPINS 1983, ŞENKARDEŞLER $e t$ al. 2014).

5. Lecania nylanderiana var. ochracea Szatala in Ann. Naturhist. Mus. Wien 50: 529 (1939)

Lectotype (designated in ŞENKARDEŞLER et al. 2014): [Iran] Montes Elburs [Elburz] centr.: in montibus ad pagum Kalak [Kalāk], in ditione oppidi Keredj [Karaj], 19.V.1937, K. H. Rechinger fil. no. 2499 (BP No. 34059 [T No. 483]!).

No original material was found in $\mathrm{W}$ after exhaustive searches, but one specimen in BP. The latter specimen was selected as the lectotype by ŞEN KARDEŞLER et al. (2014), which had been listed as "Fragm. typi" by VerSEghy (1964). This variety is a synonym of Lecania nylanderiana A. Massal. (ŞENKARDEŞLER et al. 2014).

6. Lecanora atra var. aegaeica Szatala in Denkschr. Akad. Wiss. Wien, Math.-Naturwiss. Kl. 105(1): 40 (1943)

Lectotype (designated in ŞENKARDEŞLER et al. 2014): [Greece] Rhodos [Rhodes], M. Profeta [Mt. Profitis Ilias], $700 \mathrm{~m}$, Mai 1935, K. H. Rechinger fil. s. n. (W No. 1960-9475!; isolectotype: BP No. 34038 [T No. 315]!).

The specimen in W was designated as lectotype by ŞENKARDEŞLER $e t$ al. (2014), and the specimen listed in VERSEGHY (1964) as "Fragm. typi" became an isolectotype. The lectotype was accepted as a variant of Tephromela atra (Huds.) Hafellner in ŞENKARDEşLER et al. (2014).

\section{Lecanora cengiae-samboae Szatala in Denkschr. Akad. Wiss. Wien, Math.-Naturwiss. Kl. 105(1): 37 (1943)}

Lectotype (designated in ŞENKARDEşLER et al. 2014): [Greece] Ins. Rhodos [Rhodes], Mt. Profeta [Mt. Profitis Ilias], ca. $700 \mathrm{~m}$, supra lignum, without date, K. H. Rechinger fil. s. n. (BP No. 34040 [T No. 319]!; isolectotype: W No. 19609365!). 
Szatala (1943) and ReCHINGER (1943) did not indicate the deposition of the types of this name. ŞENKARDEŞLER et al. (2014) lectotypified the specimen in $\mathrm{BP}$, and the specimen in $\mathrm{W}$ became an isolectotype. While the material in $\mathrm{W}$ is a mixture with two other taxa, namely "Caloplaca salicina (Hoffm.) f. lignicola (Somrft.)" and "Dirina repanda f. lignicola Harm." according to the label, the specimen in BP contains only one species. Comparing the label texts "auf entrindeten Zweigen" was written instead of "supra lignum", and the date was given as "Mai 1935" on the label of the isolectotype, while date was missing in the text on the lectotype. This name was accepted as a synonym of Lecanora lividocinerea (ŞENKARDEŞLER et al. 2014).

\section{Lecanora rhodi Szatala in Denkschr. Akad. Wiss. Wien,} Math.-Naturwiss. Kl. 105(1): 38 (1943)

Lectotype (designated in ŞENKARDEŞLER et al. 2014): [Greece] Ins. Rhodos [Rhodes], Mt. Profeta [Mt. Profitis Ilias], ca. $700 \mathrm{~m}$, supra saxa arenacea, without date, $K$. H. Rechinger fil. s. n. (BP No. 34044 [T No. 360]!; isolectotypes: M barcodes M-0063670, M-0063671, W No. 1960-9324!).

The deposition of the type material of this name was not indicated in the protologue (RECHINGER 1943, SzATALA 1943). Four specimens are known: the specimen BP 34044 ( T 360), which was listed as "Fragm. typi" in VERSEGHY (1964), was designated as lectotype by ŞENKARDEŞLER et al. (2014). The label text of the isolectotypes differs from the lectotype in having a statement in German ("Rhodos, M. Profeta, 700 m, auf Sandstein") and a date ("Mai 1935"), which was missed on lectotype's label, as stated in the introduction of the present paper. This species is a well-accepted taxon (LAGreca \& Lumbsch 2001, ŞENKARDEŞLER et al. 2014).

9. Lecidea aegaeica f. acrustacea Szatala in Denkschr. Akad. Wiss. Wien, Math.-Naturwiss. Kl. 105(1): 27 (1943)

Lectotype (designated in ŞENKARDEŞLER et al. 2014): [Greece], Ins. Simi [Symi], supra lignum Juniperi, without date, K. H. Rechinger fil. s. n. (BP No. 34047 [ T No. 198]!).

Two syntypes were reported, the one from Symi Island, which was listed in VERSEGHY (1964) as "Fragm.typi", was designated as lectotype in ŞENKARDEŞLER et al. (2014), and the other one from Mt. Ataviros at Rhodes Island, which is deposited in W (W 1960-9347!) was left as remaining syntype. The type specimens seem to belong to the Lecidella elaeochroma group (ŞENKARDEŞLER et al. 2014). 
10. Rinodina samothrakiana Szatala in Denkschr. Akad. Wiss. Wien, Math.-Naturwiss. Kl. 105(1): 56 (1943)

Lectotype (designated as holotype in MAYR HOFER \& POELT 1979): [Greece], Samothrake, Nordküste bei Paläopolis, 18-20. Juni 1936, K. H. Rechinger fil. s. n. (W No. 1960-9580!; isolectotype: BP No. 34097 [T 911]!).

Two original samples have been seen. The material in $\mathrm{W}$ was listed as the holotype in the revision of MAYRHOFER \& POELT (1979), while the material in BP was not included in this revision, even it was listed in VERSEGHY (1964) as "Fragm. typi". Since no internal evidence of the deposition of this specimen is given in the protologue (RECHINGER 1943, SzATALA 1943), the holotype status cannot be applied to the original material in W. Therefore, the holotype material of MAYRHOFER \& POELT (1979) should be named as lectotype, while the specimen BP 34097 (T 911) becomes isolectotype. "Samothraki, Palaeopolis, supra saxa" is written on the label of isolectotype material instead of "Samothrake, Nordküste bei Paläopolis, 18-20. Juni 1936". This species is accepted as a synonym of Rinodina confragosa (Ach.) Körb. by MAYRHOFer \& POELT (1979).

\section{DISCUSSION}

The catalogue of the type specimens deposited in BP compiled by VERSEGHY (1964) was supplemented three times (Verseghy 1968, 1974, 1981). Here, she used the term "Fragm. typi" for 10 taxa. This status is not accepted in the code.

Among her "Fragm. typi", seven, namely Buellia samothrakiana, Caloplaca servitiana, Catillaria servitii, Lecania nylanderiana var. ochracea, Lecanora cengiae-samboae, L. rhodi, and Lecidea aegaeica f. acrustacea were lectotypified by VONDRÁ K et al. (2010) and ŞENKARDEŞLER et al. (2014). The other three "Fragm. typi" (Catillaria zsakii, Lecanora atra var. aegaeica, and Rinodina samothrakiana) became isolectotype, since other type specimens were corrected to lectotype.

Acknowledgements - The author sincerely appreciate the helpful discussions with Dr John McNeill (Edinburgh), Prof. Dr Werner Greuter (Berlin), Prof. Dr Teuvo Ahti (Helsinki), and Dániel Pifkó (Budapest). The studies in BP and W were supported by The Scientific \& Technological Research Council of Turkey (TÜBİTAK, Project number 210T022), a mobility program of The Scientific \& Technological Research Council of Turkey (TÜBİTAK), as well as by the exchange program between TÜBİTAK and the Hungarian Academy of Sciences (MTA), and by two Synthesys Projects (AT-TAF-3435 and HU-TAF-1103), which were financed by the European Community Research Infrastructure Action under the FP6 and FP7 "Structuring the European Research Area" Programme. 
Összefoglaló: A Magyar Természettudományi Múzeum Növénytára zuzmógyűjteményének típuspéldányait Verseghy Klára katalogizálta (VERSEGHY 1964), majd a katalógus több alkalommal kiegészítésre került (VersEghy 1968, 1974, 1981). Ezekben a munkákban 10 taxon esetében alkalmazta a „Fragm. typi” megjelölést, mely kifejezés azonban nem szerepel a nevezéktani kódban. Mivel Verseghy „Fragm. typi” megjelölései nem tekinthetők érvényes (lekto)típus-kijelöléseknek, jelen munka sorra tárgyalja ezen - Görögországból, Magyarországról és Iránból leírt taxonok érvényes típuskijelöléseit és ezzel együtt a „Fragm. typi” megjelölésű példányok státuszát.

\section{REFERENCES}

Аввотт B. F. M. (2009): Checklist of the lichens and lichenicolous fungi of Greece. - Bibl. Lichenol. 103: $1-368$.

Coppins B. J. (1983): A taxonomic study of the lichen genus Micarea in Europe. - Bull. Brit. Mus. (Nat. Hist.), Bot. 11: 17-214.

LaGreca S. \& Lumbsch H. T. (2001): Three species of Lecanora new to North America, with notes on other poorly known lecanoroid lichens. - Bryologist 104: 204-211. https://doi.org/10.1639/0007-2745(2001)104[0204:tsolnt]2.0.co;2

Mayrhofer H. \& Poelt J. (1979): Die saxicolen Arten der Flechtengattung Rinodina in Europa. - Bibl. Lichenol. 12: 1-186.

PRINTZEN C. (1995): Die Flechtengattung Biatora in Europa. - Bibl. Lichenol. 60: 1-275.

Rechinger K. H. (1943): Flora Aegaea: Flora der Inseln und Halbinseln des Ägäischen Meeres. Denkschr. Akad. Wiss. Wien, Math.-Naturwiss. Kl. 105(1): 1-924.

ŞENKARDEŞLER A., LöKös L. \& FARKAS E. (2014): Lectotypification of names of lichen taxa described by Ödön Szatala. - Taxon 63(1): 139-145. https://doi.org/10.12705/631.9

Szatala Ö. (1926): Eine neue Flechte der Natronböden des Ungarischen Tieflandes. (A MagyarAlföld szikeseinek egy új zuzmófaja). - Magyar Bot. Lapok 24: 108.

Szatala Ö. (1943): Lichenes. - In: Rechinger K. H. (ed.): Flora Aegaea: Flora der Inseln und Halbinseln des Ägäischen Meeres. - Denkschr. Akad. Wiss. Wien, Math.-Naturwiss. Kl. 105(1): 16-58.

VERSEGHY K. (1964): Typen-Verzeichnis der Flechtensammlung in der Botanischen Abteilung des Ungarischen Naturwissenschaftlichen Museums. - Természettudományi Múzeum, Budapest, 146 pp.

Verseghy K. (1968): Nachtrag I. zum “Typenverzeichnis der Flechtensammlung in der Botanischen Abteilung des Ungarischen Naturwissenschaftlichen Museums”. - Fragm. Bot. Mus. Hist.-Nat. Hung. 6: 41-55.

Verseghy K. (1974): Nachtrag II. zum “Typenverzeichnis der Flechtensammlung in der Botanischen Abteilung des Ungarischen Naturwissenschaftlichen Museums". - Studia bot. hung. 9: 23-29.

VERSEGHY K. (1981): Nachtrag III. zum "Typenverzeichnis der Flechtensammlung in der Botanischen Abteilung des Ungarischen Naturwissenschaftlichen Museums”. - Studia bot. hung. 15: 45-47.

Vondrák J., Khodosovtsev A., LöKös L. \& Merkulova O. (2010): The identity of type specimens in BP of some names in Caloplaca. - Mycotaxon 11 1: 241-250.

https://doi.org/10.5248/111.241

(submitted: 25.09.2019, accepted: 08.11.2019) 